\title{
PENGGUNAAN BEBAT PERINEUM UNTUK MEMPERCEPAT PENYEMBUHAN LUKA PERINEUM PADA IBU NIFAS
}

\author{
Triwik Sri Mulati, Dewi Susilowati \\ Kementerian Kesehatan Politeknik Kesehatan Surakarta Jurusan Kebidanan \\ Diterima : 3 Agustus 2018, Disetujui : 20 Agustus 2018
}

\begin{abstract}
Background: Childbirth is the outcome of a process of conception (the baby) to live from the uterus to the outside world. In the process of spending the baby frequent injury in the birth canal or perineal wound (Mochtar, 2012). The purpose of this study to prove the effect of perineal bandage to cure the perineal wound. Method: The research design was quasi experiment with untreated control group design. Samples in this researh were some post partum mother who suffered wounds perineum in BPM Klaten some 118 people. Bivariate data analysis using statistical test used was $t$-tes. Result: Results from this study is that there was no influence the bandage perineum (kempitan) to cure maternal perineal wound. Perineum will cause pain and discomfort to the mother postpartum, with pain and swelling in the perineum makes the mother fear for early mobilization, to overcome this, the mother post partum have bandaging perineum (kempitan) to reduce pain and swelling, so the mother post partum can do early mobilization. Conclusion: If the mother can do early mobilization so that the maternal perineal wound may be able cured as soon as possible. Bandaging perineum (kempitan) is a bandage on the perineum given after using sanitary napkins and panty to reduce pain and swelling.
\end{abstract}

\section{Keywords: Perineal Bandage, Post Partum Mother, Maternal Perineal Wound}

\section{PENDAHULUAN}

Pada sebagian proses persalinan identik dengan terjadinya luka perineum. Luka perineum secara alami disebut ruptur, dikarenakan adanya desakan kepala janin yang terlalu cepat atau bahu pada proses persalinan yang lukanya tidak teratur dan luka perineum yang di sengaja di episiotomi untuk memperbesar muara vagina pada saat perineum dan vagina meregang sebelum keluar kepala bayi (Jones Derek, 2002).

Penanganan luka perineum dilakukan dengan melihat derajat luka, untuk derajat I jika tidak ada perdarahan tidak diperlukan penjahitan, derajat II -
IV dilakukan penjahitan (Wiknjosatro, 2008)

Luka pada perineum biasanya ringan, akan tetapi kadang-kadang terjadi luka yang luas dan berbahaya. ibu nifas akan mengalami keluhan nyeri pada perineum akibat luka jahitan peradangan ataupun bengkak dan lecet pada vagina. Peradangan adalah suatu reaksi yang normal dan merupakan hal penting untuk memastikan penyembuhan luka dan berfungsi mengisolasi jaringan rusak dan mengurangi penyebaran infeksi (Coad, 2007)

Luka perineum akan menyebabkan nyeri dan rasa tidak nyaman pada ibu nifas, hal ini akan mengganggu interaksi 
ibu dan bayi, membuat ibu lebih rentan terkena infeksi dan terjadi perdarahan jika luka perineum tidak dipantau dengan baik. Nyeri perineum akan menimbulkan dan mempengaruhi kesejahteraan perempuan secara fisik, psikologis dan sosial pada periode postnatal langsung maupun dalam jangka panjang (Richard, 2000)

Dengan adanya nyeri dan bengkak pada perineum membuat ibu takut untuk mobilisasi dini, sedangkan manfaat mobilisasi dini adalah: melancarkan pengeluaran lokea, mengurangi infeksi, mempercepat involusio alat kandungan, melancarkan peredaran darah, mencegah tromboplebitis dan akan mempercepat penyembuhan luka.

Untuk mengatasi nyeri dan bengkak perineum serta mempercepat mobilisasi dini dan kesembuhan luka perineum, maka ibu nifas diberikan bebat perineum (kempitan). Bebat perineum (kempitan) adalah balutan pada perineum yang diberikan setelah menggunakan pembalut dan celana dalam untuk mengurangi nyeri dan pembengkakan. Manfaat bebat pada luka antara lain: mengurangi nyeri, mengurangi bengkak, mengurangi ketegangan jaringan luka dan mendukung bagian otot yang terluka supaya menyatu kembali, mempercepat mobilisasi dini dan mempercepat penyembuhan luka perineum karena bebat perineum dapat mengurangi pembengkakan pada luka perineum.

Para Bidan sebaiknya menerapkan penggunaan bebat perineum pada ibu nifas untuk mengurangi nyeri dan mempercepat penyembuhan luka perineum.

Berdasarkan latar belakang diatas, penulis tertarik untuk membuktikan penggunaan bebat perineum dalam mempercepat kesembuhan luka perineum pada ibu nifas.

\section{METODE PENELITIAN}

Desain penelitian ini adalah quasi eksperiment dengan untreated control group design.

Sampel pada penelitian ini adalah Ibu nifas yang mengalami luka perineum di BPM wilayah Klaten yaitu sejumlah $118 \mathrm{ibu}$ nifas dengan pembagian $59 \mathrm{ibu}$ nifas sebagai kelompok perlakuan dan 59 ibu nifas sebagai kelompok control. Instrumen yang digunakan sebagai alat pengumpul data di dalam penelitian ini adalah lembar observasi lama penyembuhan luka perineum. Analisis data dilakukan dengan menggunakan uji ttest.

\section{HASIL PENELITIAN}

Hasil penelitian dapat dideskripsikan sebagai berikut:

Tabel 1. Distribusi frekuensi karakteristik responden berdasarkan umur pada kelompok perlakuan

\begin{tabular}{cccc}
\hline & Kategori & $\mathbf{N}$ & $\mathbf{\%}$ \\
\hline 1. & $<20$ tahun & 2 & 3 \\
2. & $20-35$ tahun & 56 & 95 \\
3. & $>35$ tahun & 1 & 2 \\
\hline & Total & 59 & 100
\end{tabular}

Berdasarkan tabel 1 terlihat bahwa mayoritas responden kelompok perlakuan pada kategori umur reproduktif (20 -35 tahun) yaitu sebanyak 56 responden $(95 \%)$. 
Tabel 2. Distribusi frekuensi karakteristik responden berdasarkan umur pada kelompok kontrol

\begin{tabular}{llcc}
\hline & Kategori & n & \% \\
\hline $\begin{array}{l}\text { 1. } \\
\text { 2. }\end{array} \quad \begin{array}{l}20-35 \text { tahun } \\
\text { tahun }\end{array}$ & 3 & 5 \\
3. $\quad>35$ tahun & 2 & 92 \\
\hline & \multicolumn{1}{c}{ Total } & 59 & 100
\end{tabular}

Berdasarkan tabel 2. dapat dilihat bahwa bahwa mayoritas responden pada kelompok kontrol pada kategori umur reproduktif (20 -35 tahun) yaitu sebanyak 54 responden $(92 \%)$.

Tabel 3. Distribusi frekuensi karakteristik responden berdasarkan paritas pada kelompok perlakuan

\begin{tabular}{lcc}
\hline \multicolumn{1}{c}{ Kategori } & N & P \\
\hline 1. Primipara & 27 & 46 \\
2. Multipara & 32 & 54 \\
3. Grandemultipara & - & \\
\hline \multicolumn{1}{c}{ Total } & 59 & 100
\end{tabular}

Berdasarkan tabel 3. dapat dilihat bahwa mayoritas responden kelompok perlakuan pada kategori paritas multipara yaitu sebanyak 32 responden $(54 \%)$.

Tabel 4. Distribusi karakteristik responden berdasarkan paritaspada kelompok kontrol

\begin{tabular}{lcc}
\hline \multicolumn{1}{c}{ Kategori } & N & Prosentase \\
\hline 1. Primipara & 25 & 42 \\
2. Multipara & 34 & 58 \\
3. Grandemultipara & - & - \\
\hline \multicolumn{1}{c}{ Total } & 59 & 100 \\
\hline
\end{tabular}

Berdasarkan tabel 4 terlihat bahwa mayoritas responden kelompok kontrol pada kategori paritas multipara yaitu sebanyak 34 responden (58\%).
Tabel 5. Distribusi frekuensi karakteristik responden berdasarkan mobilisasi dini pada kelompok perlakuan

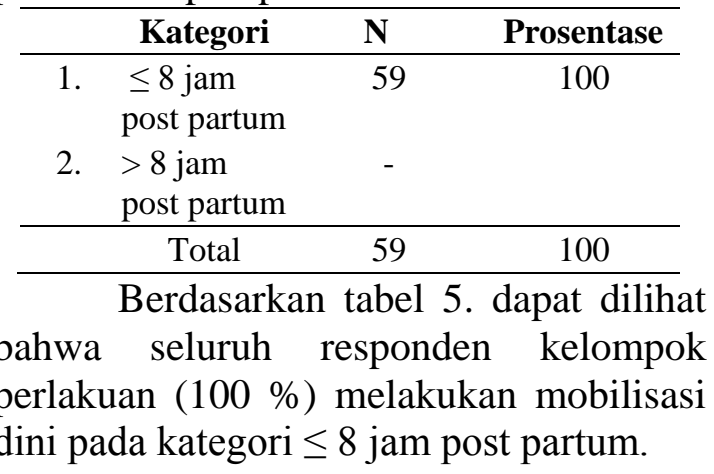

Tabel 6. Distribusi frekuensi karakteristik responden berdasarkan mobilisasi dini pada kelompok kontrol

\begin{tabular}{cccc}
\hline & Kategori & $\mathbf{N}$ & $\%$ \\
\hline $1 . \quad \begin{array}{l}\leq \text { jam } \\
\text { post partum }\end{array}$ & 59 & 100 \\
$2 . \quad \begin{array}{l}>\text { jam } \\
\text { post partum }\end{array}$ & - & - \\
\hline & Total & 59 & 100 \\
\hline
\end{tabular}

Berdasarkan tabel 6. dapat dilihat bahwa seluruh responden kelompok kontrol (100\%) melakukan mobilisasi dini pada kategori $\leq 8$ jam post partum.

Tabel 7. Distribusi frekuensi lama penyembuhan luka perineum pada kelompok perlakuan

\begin{tabular}{|c|c|c|c|}
\hline & Kategori & $\mathbf{N}$ & $\%$ \\
\hline 1. & $\leq 7$ hari & 47 & 80 \\
\hline \multirow[t]{2}{*}{2.} & $>7$ hari & 12 & 20 \\
\hline & Total & 59 & 100 \\
\hline
\end{tabular}
diketahui bahwa mayoritas responden kelompok perlakuan yang diberikan bebat perineum mengalami penyembuhan luka $\leq 7$ hari yaitu sebanyak 47 responden $(80$ $\%)$. 
Tabel 8. Distribusi frekuensi lama penyembuhan luka perineum pada kelompok kontrol

\begin{tabular}{llll}
\hline & Kategori & $\mathbf{N}$ & $\mathbf{\%}$ \\
\hline 1. & $\leq 7$ hari & 39 & 66 \\
2. & $>7$ hari & 20 & 34 \\
\hline \multicolumn{2}{c}{ Total } & 59 & 100 \\
\hline \multicolumn{2}{c}{ Berdasarkan } & tabel & 8.
\end{tabular}

diketahui mayoritas responden kelompok kontrol (tidak diberikan bebat perineum tapi yang masih diberikan perawatan perineum seperti biasanya) mengalami penyembuhan luka $\leq 7$ hari yaitu sebanyak 39 responden (66\%).

Untuk mengetahui pengaruh penggunaan bebat perineum (kempitan) terhadap lama penyembuhan luka perineum maka dilakukan uji statistic $t$ test. Hasil uji statistik $\mathrm{p}=0.064$, dimana $\mathrm{p}>0.05$ sehingga di simpulkan bahwa tidak ada pengaruh antara penggunaan bebat perineum (kempitan) terhadap lama penyembuhan luka perineum.

\section{PEMBAHASAN}

Dari hasil uji statistik t-test dapat diketahui bahwa nilai $\mathrm{p}=0.064$, dimana $\mathrm{p}$ $>0.05$ sehingga di simpulkan bahwa tidak ada pengaruh antara penggunaan bebat perineum (kempitan) terhadap lama penyembuhan luka perineum.

Hal tersebut terjadi karena pada kelompok kontrol lebih dari $50 \%$ mengalami kesembuhan luka pada $\leq 7$ hari juga. Meskipun secara hitungan distribusi frekuensi, bahwa seluruh responden pada kelompok perlakuan yang diberi bebat perineum mengalami kesembuhan $\leq 7$ hari, tapi karena pada kelompok kontrol yang tidak diberi bebat perineum juga menunjukkan penyembuhan luka yang cepat $(66 \%)$ maka untuk uji statistic menunjukkan tidak ada pengaruh antara penggunaan bebat perineum terhadap penyembuhan luka perineum.

Teori mengungkapkan bahwa kesembuhan luka dipengaruhi oleh banyak faktor, termasuk faktor nutrisi, mobilisasi, psikologis, sehingga tidak hanya karena adanya pembebatan perineum. Oleh karena itu sangat bisa di mengerti bahwa pada kelompok yang tidak menggunakan bebat perineum pun juga mengalami kesembuhan luka yang cepat $(\leq 7$ hari). Tetapi pada penelitian ini sebenarnya juga membuktikan bahwa mayoritas responden yang memakai bebat perineum $(80 \%)$ mengalami kesembuhan luka yang cepat ( $\leq 7$ hari). Dengan data tersebut sebenarnya menunjukkan bahwa bebat perineum kemungkinan mempengaruhi lebih cepatnya kesembuhan luka perineum karena seluruh responden $(100 \%)$ yang diberi bebat melakukan mobilisasi dini $\leq 8$ jam post partum. Secara teori disebutkan bahwa mobilisasi dini dapat mempercepat kesembuhan luka perineum.

\section{KESIMPULAN DAN SARAN}

Berdasarkan hasil penelitian dapat ditarik kesimpulan sebagai berikut :

1. Berdasar hasil analisis data dan pembahasan dapat disimpulkan sebagai berikut: Sebagian besar responden $(80$ $\%)$ pada kelompok kontrol yang memakai bebat perineum mengalami kesembuhan luka yang cepat pada $\leq 7$ hari.

2. Sebagian besar responden $(66 \%)$ pada kelompok kontrol yang tidak memakai bebat perineum mengalami kesembuhan luka yang cepat pada $\leq 7$ hari.

3. Tidak ada pengaruh antara penggunaan bebat perineum dengan kesembuhan luka perineum. 
Saran yang diajukan yaitu:

1. Bagi Masyarakat (Khususnya ibu post partum)

Para ibu post partum lebih aktif bertanya dan mencari informasi tentang penyembuhan luka perineum dan menerapkan penanganan tersebut, khususnya tentang bebat perineum.

2. Bagi petugas kesehatan

Petugas kesehatan khususnya Bidan diharapkan dapat menerapkan penggunaan menggunakan bebat perineum (kempitan) pada luka perineum untuk mempercepat penyembuhan luka perineum.

\section{DAFTAR RUJUKAN}

Coad, Jane. 2007. Anatomi dan Fisiologi untuk Bidan. Jakarta: EGC

Jones, Derek Liewellyn.2002.Dasr-dasar Obstrtri dan Ginekologi

Mochtar, Rustam. 2008. Sinopsis Obstetri. Jakarta : EGC

Richard, 2000. Perineal massage for prevention of perineal trauma in childbirth, The Jurnal of America.

Wiknjosastro H. Ilmu Kebidanan. Edisi

ke-4 Cetakan ke-2. Jakarta:

Yayaan Bina Pustaka Sarwono

Prawirohardjo 